\title{
The effects of carvedilol on ischemia-reperfusion injury in the rat testis
}

\author{
B.S. Parlaktas, D. Atilgan, Y. Gencten, A. Akbas, F. Markoc, F. Erdemir, H. Ozyurt, N. Uluocak \\ Department of Urology (BSP, DA, YG FE, NU); Department of Biochemistry (AA, HO) and Department of \\ Pathology (FM), Faculty of Medicine, Gaziosmanpasa University, Tokat, Turkey
}

\section{ABSTRACT}

Objective: To analyze the oxidative damage and histopathological alterations caused by ischemia-reperfusion (I/R) injury and ameliorative effects of carvedilol (CVD) in the rat testis.

Materials and Methods: Twenty-one male rats were randomized into 3 groups as follows: Group I ( $\mathrm{n}=7)$; control (sham) group, Group II $(\mathrm{n}=7) ; \mathrm{I} / \mathrm{R}$ group, in which I/R injury was performed by torsing the left testis $720^{\circ}$ clockwise for 2 hours and detorsing for 2 hours. Group III ( $\mathrm{n}=7)$; CVD treatment group; in addition to I/R process, one-dose of CVD was administered ( $2 \mathrm{mg} / \mathrm{kg}$, i.p) $30 \mathrm{~min}$. before detorsion. Levels of antioxidant enzymes, superoxide dismutase (SOD) and glutathione peroxidase (GSH-Px) and levels of malondialdehyde (MDA) and protein carbonyl (PC) were determined in testicular tissues and serum of rats. Testicular tissues were also examined histopathologically and Johnsen scores were determined.

Results: Activities of SOD and GSH-Px in serum and testicular tissues were increased by I/R, but administration of CVD decreased these levels $(p<0.001$ and $p=0.001$ ). Significantly increased MDA levels in serum and testicular tissues were decreased by CVD treatment $(\mathrm{p}<0.001$ and $\mathrm{p}=0.001)$. Concerning PC levels in serum and testicular tissues, there was no statistically significant difference between the groups $(p=0.989$ and $p=0.428$ ). There was not a statistically significant difference in terms of mean Johnsen scores between the groups ( $p=0.161)$.

Conclusions: Administration of CVD decreased oxidative damage biochemically in the rat testis caused by I/R injury, but histopathologically no change was observed between all of the groups.

\section{ARTICLE INFO}

Key words:

Carvedilol [Supplementary

Concept]; Reperfusion;

Ischemia; Testis; Oxidative

Stress; Antioxidants

Int Braz J Urol. 2014; 40: 109-17

Submitted for publication:

March 25, 2013

Accepted after revision:

September 04, 2013

\section{INTRODUCTION}

Ischemia-reperfusion ( $\mathrm{I} / \mathrm{R})$ injury is a deleterious clinical entity in the organism that occurs when blood circulation is restored after an episode of acute ischemia. In this type of injury the blood supply of the tissue is interrupted initially which leads to damage of metabolically ac- tive tissues, but the restoration of blood flow to the tissues, which initiates paradoxic cascade of events, leads to further cellular and tissue damage eventually (1). There is increasing evidence that the oxidative stress (OS), which is associated with the over-production of reactive oxygen species (ROS), constitutes the basic pathophysiological process of $\mathrm{I} / \mathrm{R}$ injury $(1,2)$. 
In clinical settings, testicular torsion (TT) is a typical I/R injury of the testicular tissues, which is one of the most serious urologic emergencies encountered mostly in newborn and adolescent males (3). TT causes testicular injury leading to potential serious sequela of subfertility, so immediate diagnosis and intervention is mandatory $(3,4)$. Although the main pathological mechanism of the testicular injury following TT has not been completely understood, the I/R established during torsion and detorsion and OS generated by these events has been implicated as the main factors in cellular and tissue damage $(4,5)$. In addition to showing the activation of several antioxidant defense mechanisms to avoid the tisssue damage due to ROS, which included the production of endogenous antioxidant enzymes such as superoxide dismutase (SOD) and glutathione peroxidase (GSH-Px), the alterations in the serum and tissue levels of lipid peroxidation product malondialdehyde (MDA) and protein denaturation product protein carbonyl (PC) have also been been analyzed in related studies to delineate the damaging effects of ROS (1-5).

In numerous previous studies it has been clearly shown that the administration of exogenous antioxidants or ROS scavenger agents have prevented or minimized the oxidative injury in testicular tissues due to TT in rats (3-9). Carvedilol [1-[carbazolyl-(4)-oxy]-3-[(2-methoxyphenoxyethl)amino]-2-propanol] is a third-generation vasodilator agent which is used in the treatment of hypertension, ischemic heart disease and congestive heart failure $(10,11)$. It selectively blocks $\alpha 1$-receptors and non-selectively antagonizes $\beta 1$ and $\beta 2$-adrenoceptors $(1,11)$. Carvedilol (CVD) and some of its metabolites also display antioxidant activity and this antioxidant characteristics of CVD have been shown in previous in vitro studies and animal models (10-14). In this experimental stu$\mathrm{dy}$, it was aimed to assess the potential antioxidant effects of CVD in a rat model of testicular I/R injury. For this purpose, the biochemical and pathological effects of $\mathrm{I} / \mathrm{R}$ and CVD in testicular tissues and serum of rats have been investigated. To our knowledge, this is the first study in the English literature which investigated the antioxidant effects of CVD against I/R in the rat testicular tissues.

\section{MATERIALS AND METHODS}

\section{Animals}

The study was conducted on 21 male adult Wistar-albino rats, 5-6 months old and weighing between 270-330g. The protocol of the study was approved by the local Ethics Committee of Gaziosmanpasa University School of Medicine (2011-HADYEK-018), in which the animal care and experimental procedures were executed in compliance with the principles of the NIH Guide for the Care and Use of Laboratory Animals (NIH publication no. 85-23, revised 1985). The rats were housed in cages ( 3 animals/cage) under temperature controlled standard conditions with free access to standard rodent food and water.

\section{Experimental design}

The animals were anaesthetized with intraperitoneal ketamine injection $(50 \mathrm{mg} / \mathrm{kg})$. All of the surgical procedures were performed under sterile conditions through standart left inguinoscrotal incisions. After entrance to the scrotum, tunica vaginalis was opened and the left testis was delivered to the surgical field. The left testis was rotated $720^{\circ}$ in a clockwise direction and maintained torsed by fixing it to the scrotum by $4 / 0$ polyglactin suture for 2 hours with the closure of inguinoscrotal incision. Afterwards the spermatic cord was detorsed and the testis was reperfused for additional 2 hours. At the end of the ischemia and reperfusion period (4 hours) left orchiectomy was performed, $3-4 \mathrm{~mL}$ of blood was drawn from the inferior vena cava of each rat and the animals were sacrificed by decapitation.

The rats were randomly divided into three experimental groups as follows; Group $1(n=7)$, sham operated control group (sham), the rats in this group underwent excision of the left testis after sham operation. Group 2, ( $\mathrm{n}=7)$, ischemia-reperfusion group (I/R); this group of animals served as the injurious control group and underwent torsion/detorsion procedures as explained before. Group 3, $(\mathrm{n}=7)$, comprised the CVD treatment group $(\mathrm{I} / \mathrm{R}+\mathrm{CVD})$ in addition to $\mathrm{I} / \mathrm{R}$ process the animals in this group received CVD ( $2 \mathrm{mg} / \mathrm{kg}$, i.p.) $30 \mathrm{~min}$. before detorsion. Carvedilol tablets (Dilatrend $^{\circledR}, 6.25 \mathrm{mg}$, Roche, Turkey) were dissolved in 
normal saline as explained in a previous study and administered intraperitoneally (10). The harvested testicular tissues were longitudionally bisected. The halves of the testicular tissues were immediately stored at $-80^{\circ} \mathrm{C}$ pending for biochemical analysis and the remainder halves were fixed in $10 \%$ formalin for histopathological examination.

\section{Biochemical assays}

All of the testicular tissues were washed three times in cold isotonic saline $(0.9 \%[\mathrm{v} / \mathrm{w}])$ solution and wet tissue weights were obtained. The tissues were then homogenized in ice-cold Tris- $\mathrm{HCl}$ buffer solution $(\mathrm{pH} 7.4,0.2 \mathrm{mmoL} / \mathrm{L}$ and 50/39.9 [v/v]), within a homogenizer (Ultra Turrax Type T25-B; IKA Labortechnic, Staufen, Germany) for $2 \mathrm{~min}$ at $11200 \mathrm{x}$ g. The homogenate was centrifuged at $3500 \mathrm{x} \mathrm{g}$ for $60 \mathrm{~min}$. and a supernatant was obtained. The levels of GSH-Px were determined in the supernatant, and MDA and PC levels were studied in the homogenate. For a further extraction procedure, the supernatant was extracted in ethanol/chloroform mixture $(5 / 3, v / v)$. After a second centrifugation at $3500 \mathrm{x} g$ (20 min.), the clear upper layer (the ethanol phase) was taken and used for SOD activity determination. All procedures were performed at $4^{\circ} \mathrm{C}$ and icepacks were used to maintain the temperature during the homogenization procedure. The principle of the SOD activity determination method was based on the inhibition of nitroblue tetrasolium reduction by the xanthine-xanthine oxidase system as a superoxide radical generator. One unit of SOD was defined as the enzyme activity causing 50\% inhibition in the nitroblue tetrazolium reduction rate. The SOD activity was expressed as units per mg tissue protein $(\mu / \mathrm{mg}$ prot). GSH-Px was measured by the enzymatic reaction which was initiated by addition of $\mathrm{H}_{2} \mathrm{O}_{2}$ to the reaction mixture containing reduced glutathione, NADPH and glutathione reductase and the change in the absorbance at $340 \mathrm{~nm}$ was monitored by spectrophotometer. The activity of the enzyme was given in $\mu / \mathrm{mg}$ prot. The MDA levels in testicular tissues were analyzed by a method based on the reaction with thiobarbituric acid at $90-100^{\circ} \mathrm{C}$. In the thiobarbituric acid test reaction, MDA or MDA-like substances and thiobarbituric acid react together to produ- ce a pink pigment with an absorption maximum of $532 \mathrm{~nm}$. The results were expressed as nanomol per gram wet tissue (nmoL/g wet tissue) calculated by using a standard graphics, which was prepared with serial dilutions of standard 1,1,3,3-tetramethoxypropane. The PC contents were determined spectrophotometrically (GBC Cintra 10 E UV/Visible spectrophotometry, Melbourne, Australia) with the reaction of the carbonyl group with 2,4-dinitrophenylhydrazine to form 2,4-dinitrophenylhydrazone. The results were given as nanomoles of protein carbonyl per milligram of protein.

\section{Histopathological evaluation}

The testicular tissues were fixed in 10\% neutral formaldehyde solution. The tissues were processed for paraffin embedding and $5 \mu \mathrm{m}$ thick paraffin sections were obtained and stained with hematoxylin and eosin staining for light microscopic analysis. The same pathologist who was unaware of the experimental procedures examined the samples histopathologically. The testes were examined for the presence of coagulation type necrosis and the morphological changes in the nucleus of the germ cells. Coagulation type necrosis was classified into four grades as follows: Grade 0 showed an absence of coagulative necrosis in the seminiferous tubules, Grade 1 slight coagulation, $<25 \%$ of the seminiferous tubules containing evidence of necrosis, Grade 2 indicated moderate degree of coagulation with $\geq 25 \%$ of the tubules containing variable degrees of necrosis, Grade 3 indicated severe coagulation with $\geq 75$ $\%$ of the tubules demonstrated necrosis. A total of twenty tubular sections for each testicular tissue were evaluated and to assess spermatogenesis mean Johnsen score was calculated according to the Modified Johnsen Scoring system explained elsewhwere (Table-1) (15).

The findings of histopathological evaluation are shown in Figures 1 to 3. The testes of rats in Group 1 (control group) indicated the presence of normal testicular structure and seminiferous tubular morphology with full spermatogenesis (Figure-1). The coagulative necrosis (CN) seen in different grades in all groups and the distortion of tubules are presented in Figure-2. Furthermore, degeneration in the germ cells characterized 
Table 1 - Histological criteria and the modified Johnsen score system for assessment of spermatogenesis.

\begin{tabular}{lc}
\hline Score & Histologic properties \\
\hline 10 & Full spermatogenesis \\
9 & Slightly impaired spermatogenesis, many late spermatids, disorganized epithelium \\
8 & Less than five spermatozoa per tubule, few late spermatids \\
7 & No spermatozoa, no late spermatids, many early spermatids \\
6 & No spermatozoa, no late spermatids, few early spermatids \\
5 & No spermatozoa or spermatids, many spermatocytes \\
4 & No spermatozoa or spermatids, few spermatocytes \\
3 & Spermatogonia only \\
2 & No germinal cells, Sertoli cells only \\
1 & No seminiferous epithelium \\
\hline
\end{tabular}

Figure 1 - Histological sections of rat testes stained with hematoxylin and eosin. Full spermatogenesis is seen in control group (H-E, X400).

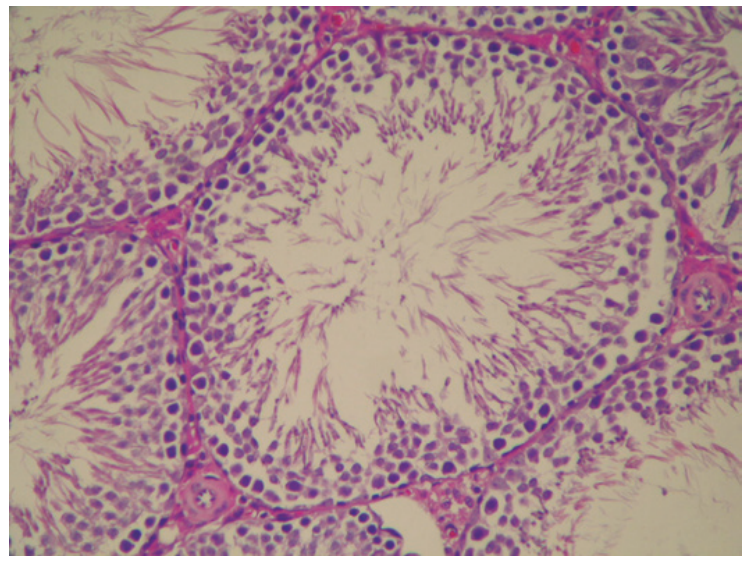

Figure 2 - Coagulative necrosis (CN) in the seminiferous tubules. a) Grade 1 coagulative necrosis, a few seminiferous tubules containing evidence of necrosis; b) Grade 2 coagulative necrosis; c) Grade 3 coagulative necrosis with loss of seminiferous tubule epithelium, edema and sloughed germinal cells (H-E, X200).
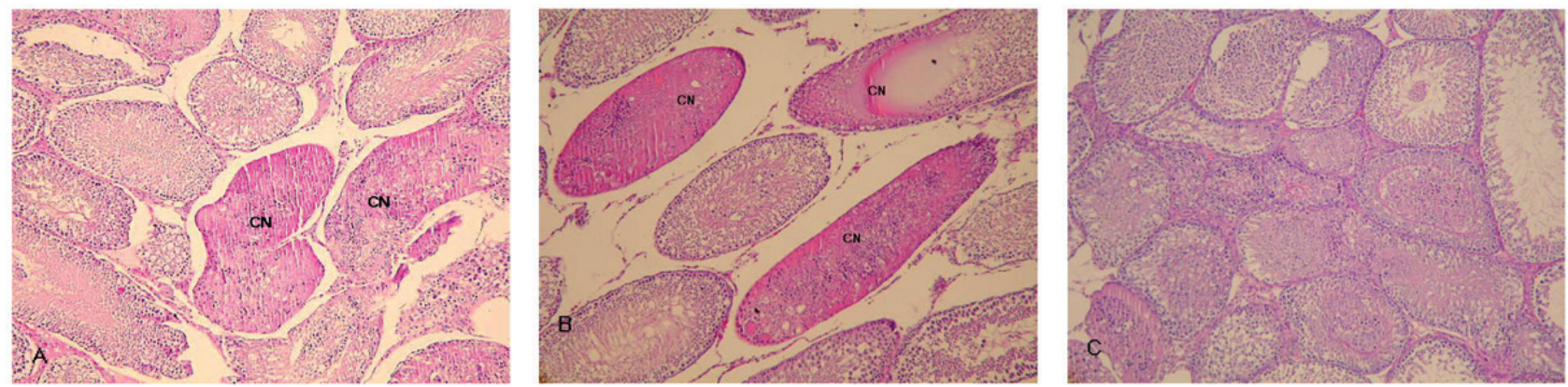
by giant cells and vesicular nuclear changes were seen in $\mathrm{I} / \mathrm{R}$ group rats (Figure-3).

\section{Statistical Analysis}

Kruskall-Wallis tests were used to compare the biochemical and histopathological parameters

Figure 3 - Giant cells and vesicular nuclear changes in the germ cells after $\mathrm{I} / \mathrm{R}$ (H-E, X400).

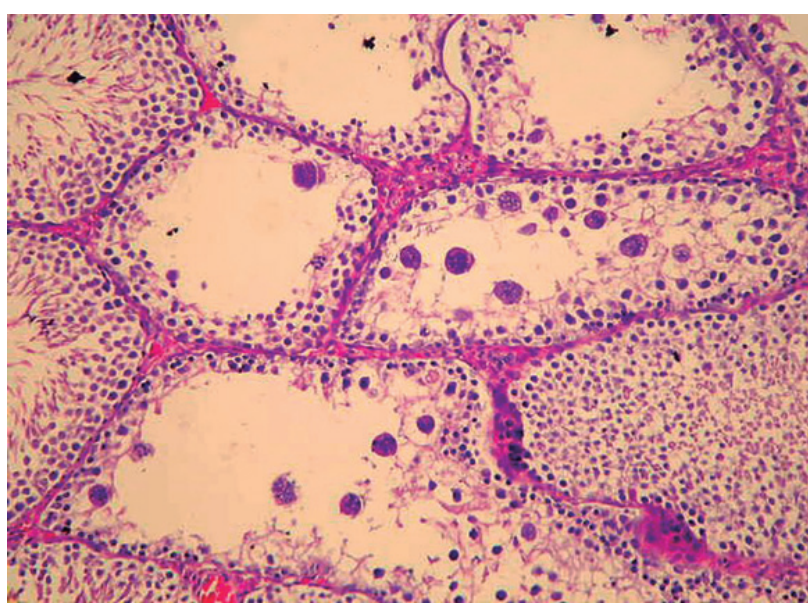

among groups. When Kruskall-Wallis test results were significant, Bonferroni adjusted Mann-Whitney $U$ test was used in the paired comparison. The continuous variables are presented as the mean \pm standard deviation and range (min-max values). Categorical variables were compared by ChiSquare test. Categorical variables are presented as counts and percentages. A p-value $<0.05$ was considered significant. Analyses were performed by using commercial software (IBM SPSS Statistics 20, SPSS inc., an IBM Co., Somers, NY).

\section{RESULTS}

The results of serum SOD, MDA, GSH-PX and PC values in all groups are presented in Table- 2 . The serum MDA level increased in the $I / R$ group in comparison to sham group but single dose CVD administration reduced serum MDA levels significantly ( $p<0.001)$. However, there was no significant difference between groups in terms of PC levels ( $p=$ 0.989). Similarly, SOD and GSH-Px activities were also increased in the $\mathrm{I} / \mathrm{R}$ group when compared to control group, but CVD treatment reduced SOD and

Table 2 - The serum antioxidant activities and levels of MDA and PC in all groups and statistical comparisons.

\begin{tabular}{lcccc}
\hline & Group 1 & Group 2 & Group 3 & P \\
\cline { 2 - 3 } & $($ SHAM) $(\mathrm{n}=7)$ & $(\mathrm{I} / \mathrm{R})(\mathrm{n}=7)$ & $(\mathrm{IR}+\mathrm{CVD})(\mathrm{n}=7)$ & \\
\hline SOD & $12.87 \pm 0.31$ & $16.78 \pm 0.64$ & $11.73 \pm 0.65$ & $<0.001$ \\
$(\mathrm{U} / \mathrm{mL})$ & $(12.42-13.3)$ & $(15.7-17.52)^{\mathrm{a}}$ & $(11.05-12,72)^{\mathrm{a}, \mathrm{b}}$ & \\
MDA & $1.62 \pm 0.28$ & $3.24 \pm 0.62$ & $1.17 \pm 0.1$ & \\
$(\mu \mathrm{mol} / \mathrm{L})$ & $(1.28-2.07)$ & $(2.46-3.99)^{\mathrm{a}}$ & $(1.05-1.32)^{\mathrm{a}, \mathrm{b}}$ & $<0.001$ \\
GSH-Px & $1.97 \pm 0.48$ & $3.85 \pm 0.92$ & $1.9 \pm 0.33$ & \\
$(\mathrm{U} / \mathrm{mL})$ & $(1.37-2.55)$ & $(1.98-4.68)^{\mathrm{a}}$ & $(1.42-2.46)^{\mathrm{b}}$ & 0.006 \\
$\mathrm{PC}$ & $403.79 \pm 44.27$ & $400.83 \pm 46.83$ & $426.23 \pm 94.29$ & \\
$(\mathrm{nmoL} / \mathrm{mL})$ & $(353.45-470.18)$ & $(340.36-465.82)$ & $(360-597.82)$ & 0.989 \\
\hline
\end{tabular}

Data are shown as mean \pm standard deviation and range (min-max).

a: There was statistically significant difference from group 1.

b: There was statistically significant difference from group 2.

SOD = Superoxide dismutase $;$ MDA = Malondialdehyde; $\mathbf{G S H}-\mathbf{P x}=$ Glutathione peroxidase $; \mathbf{P C}=$ Protein carbonyl . 
GSH-Px activities in comparison to the $\mathrm{I} / \mathrm{R}$ group (p $<0.001$ and $p=0.006$, respectively).

The results and the analysis of testicular tissue MDA, PC, SOD and GSH-Px values in all groups are presented in Table- 3 . The tissue levels of MDA increased in the I/R group in comparison to sham-operated group and a single dose CVD treatment ameliorated MDA levels in testicular tissues significantly $(p=0.001)$. Statistically significant difference was not detected between groups in terms of PC levels $(p=0.428)$. SOD and GSH-Px activities increased in the I/R group but one dose of CVD injection caused decreased SOD and GSH-Px activities in comparison to I/R group as well $(\mathrm{p}<0.001$ and $\mathrm{p}$ $=0.001$, respectively).

At histopathological examination of the testicular tissues, there was no statistically significant difference between all of the groups in terms of mean Johnsen scores and nuclear changes in germ cells ( $p=0.161$ and $p=0.115$, respectively). Altough $\mathrm{I} / \mathrm{R}$ caused increase in grade 1 coagulation necrosis in testicular tissue significantly, CVD treatment did not provide a decline in the proportion of grade 1 coagulative necrosis in comparison to $\mathrm{I} / \mathrm{R}$ group $(\mathrm{p}=$ 0.018) (Table-4).

\section{DISCUSSION}

Although it is treated appropriately within the recommended time, TT may still result in testicular damage and infertility. It has previously been shown that the mammalian testes are highly sensitive to the oxidative insult and the most important component of post-torsion testicular damage is oxidative injury $(2-9,16,17)$. The pathogenetic mechanism of $I / R$ injury has been mostly attributed to the overgeneration of ROS $(4,7,8,10,11,18)$. The ROS have destructive effects on various cellular components in the organism leading to increased microvascular permeability, interstitial edema, loss of membrane integrity, impaired vasoregulation, inflammatory cell infiltration, parenchymal cells dysfunction and eventually necrosis $(2,5,8,15)$.

During the ischemic phase of $I / R$ process a hypoxic condition develops in the testicular tissues due to disruption of the blood flow. Consequently, hypoxic conditions prevail and tissue ATP production decreases because of limited oxygen available in the tissue. Calcium influx into the intracellular compartment increases, leading to conversion of hypoxanthine deoxygenase to xanthine

Table 3 - The antioxidant enzyme activities and levels of MDA and PC in testicular tissues of all groups and statistical comparisons.

\begin{tabular}{lcccc}
\hline & Group 1 & Group 2 & Group 3 & p \\
\cline { 2 - 4 } & $($ SHAM $)(\mathrm{n}=7)$ & $(\mathrm{I} / \mathrm{R})(\mathrm{n}=7)$ & $(\mathrm{I} / \mathrm{R}+\mathrm{CVD})(\mathrm{n}=7)$ & \\
\hline SOD & $0.04 \pm 0.01$ & $0.14 \pm 0.01$ & $0.07 \pm 0.02$ & $<.001$ \\
(U/mg protein) & $(0.03-0.05)$ & $(0.12-0.15)^{\mathrm{a}}$ & $(0.04-0.09)^{\mathrm{b}}$ & \\
MDA & $52.88 \pm 20.63$ & $221.95 \pm 38.13$ & $88.73 \pm 44.36$ & \\
(nmoL/g wet tissue) & $(18.75-81.63)$ & $(192.18-299.34)^{\mathrm{a}}$ & $(27.54-158.33)^{\mathrm{b}}$ & 0.001 \\
GSH-Px & $3.67 \pm 1.41$ & $10.56 \pm 2.97$ & $3.58 \pm 0.71$ & \\
(U/g protein) & $(1,54-5,31)$ & $(7.41-15.01)^{\mathrm{a}}$ & $(2.51-4.49)^{\mathrm{b}}$ & 0.001 \\
PC & $55.38 \pm 23.16$ & $61.67 \pm 30.47$ & $76.78 \pm 34.52$ & \\
(nmoL/mg prot) & $(31.79-95.42)$ & $(27.9-117.17)$ & $(35.15-144.09)$ & 0.428 \\
\hline
\end{tabular}

Data are shown as mean \pm standard deviation and range (min-max).

a: There was statistically significant difference from group 1 .

b: There was statistically significant difference from group 2 .

SOD = Superoxide dismutase; $\mathbf{M D A}=$ Malondialdehyde; $\mathbf{G S H}-\mathbf{P x}=$ Glutathione peroxidase; $\mathbf{P C}=$ Protein carbonyl. 
Table 4 - Johnsen scores and other histologic features in the testicular tissues of rats.

\begin{tabular}{lcccc}
\hline & Group 1 & Group 2 & Group 3 & p \\
\cline { 2 - 4 } & (SHAM) $(\mathrm{n}=7)$ & $(\mathrm{I} / \mathrm{R})(\mathrm{n}=7)$ & $(\mathrm{IR}+\mathrm{CVD})(\mathrm{n}=7)$ & \\
\hline Johnsen Score & $9.37 \pm 0.37$ & $8.77 \pm 0.71$ & $8.83 \pm 0.62$ & 0.161 \\
& $(8.95-9.9)$ & $(7.35-9.3)$ & $(7.9-9.8)$ & \\
Grade of coagulative necrosis & & & & $0.018^{*}$ \\
0 & $5(71.4)$ & 0 & 0 & \\
1 & $2(28.6)$ & $5(71.4)$ & $4(57.1)$ & \\
2 & 0 & $2(28.6)$ & $2(28.6)$ & \\
3 & 0 & 0 & $1(14.3)$ & \\
Nuclear changes in germ cells $(+)$ & 0 & $1(14.3)$ & $3(42.9)$ & 0.115 \\
\hline
\end{tabular}

Data are shown as mean \pm standard deviation (min-max) and $n(\%)$.

*: There was statistically significant difference between group 1 and other groups.

oxidase, which is a superoxide generator enzyme $(2,7,8,17,18)$. Additionally, ischemic state stimulates the chemotactic factors and leads to migration of polymorphonuclear leukocytes to the ischemic region, which also generates superoxide radicals after reperfusion $(17,18)$. Restoration of the blood flow reverses this ischemic state but paradoxically the harmful insult to the tissue increases. Oxygen becomes abundant during the first 60-90 minutes of reperfusion which promotes the toxic burst of free oxygen radicals to invade neutrophils, macrophages and residual parenchymal cells in the affected tissues $(18,19)$. Consequently, the enzymatic antioxidant defense system including SOD and GSH-Px react to scavenge the deleterious effects of free radicals to protect tissues from $I / R$ injury $(1,3,4)$. The clinical implications of these biochemical events can be summarized as follows: at the beginning torsion causes damage of the testicular tissues due to ischemic process. After rescue or detorsion procedure of the testis this damage is aggravated by reperfusion injury (20-22). In the early phases of tissue destruction the production of excessive amounts of ROS reacts with membrane lipids and results in lipid peroxidation, eventually leading to loss of cellular components of the tissue $(21,22)$.
Biochemical markers and parameters are more sensitive in the acute phase of such injuries. In other words, the changes in biochemical parameters occur earlier in comparison to morphologic changes, so for the evaluation of testicular damage after unilateral TT biochemical analysis would be more informative than the histologic and morphologic studies in the acute phase of I/R models (23). The aim of this study was to investigate the early biochemical changes in the testicular tissues of rats subjected to I/R injury and determine the efficacy of CVD administration on this deleterious condition, which is an antihypertensive, vasodilator agent but also has potent antioxidant activity $(1,10,12,13)$. The changes in the tissue antioxidant enzyme activities and tissue levels of MDA and PC in the I/R group showed evidence of $I / R$ injury in the torted rat testis. According to the statistical analysis of the biochemical results the prominent beneficial effects of CVD treatment could also be seen.

In the present study, it was observed that the tissue levels of MDA, which is a lipid destruction product, was significantly increased in serum and testicular tissues of $\mathrm{I} / \mathrm{R}$ group rats. The elevation of MDA levels supported I/R injury on testicular tissues. However, the levels of MDA returned closer to sham group upon CVD administration. 
The changes in the tissue levels of PC could not be argued in the same way of MDA, because varying types of changes were determined in serum and the testicular tissue levels of PC in the I/R group. According to our results, CVD acted as a prooxidative agent in testicular tissues. In other words, CVD increased protein oxidation in testicular tissues. But these changes in PC levels and comparisons between the groups with regard to PC levels were insignificant.

The main treatment strategy in the prevention of the harmful effects of oxidative stress was the use of antioxidants in previous studies. In this context, to date various drugs and chemicals have been used to protect testes against I/R injury, such as $\mathrm{N}$-acetyl cysteine, zofenopril, caffeic acid phenethyl ester (CAPE), erdosteine, L-carnitine, melatonin, edaravone, dopamine, vit $\mathrm{C}$, trimetazidine and Ginkgo biloba (EGb 761) $(2,4,5,7,8,17,23-25)$. As a non-selective $\beta_{1} \beta_{2}$ and $\alpha_{1}$-blocker agent, the mechanisms of antioxidant action of CVD has not been fully understood, but the greatest antioxidant activity has been attributed to its main metabolites, which are the hydroxylated compounds SB 211475, BM 910228 and SB 209995 (26). The suppressor activity of CVD on superoxide activity in neutrophils and endothelial protecting function in I/R injuries in liver, lung, skeletal muscle, renal and heart tissues has also been reported $(1,10,13)$. According to these studies, CVD also exerted anti-ROS and endogenous antioxidant preserving functions, which led to protective properties against $O S$ and successive I/R injury $(1,11,13,26)$.

CVD is a highly lipophilic compound that is rendering a high distribution volume and extensively bounding to high lipid containing tissues. This molecular positioning of the compound within the lipid bilayer and ability to pass through all biological membranes, to enter cells and their subcellular compartments gave CVD the tendency to donate electrons easily to scavenge the ROS $(11,26)$. These anti-ROS activities may be clinically relevant in post-ischemic conditions, such as testis after TT, which seemed to be protective and may have additional therapeutic value in such I/R injuries by free radical scavenging properties $(11,26)$. This present study, which aimed to evaluate the short term protective effects of CVD on $\mathrm{I} / \mathrm{R}$ injury of the rat testis, has shown that rats treated with CVD before detorsion process sustained improved oxidative parameters. The antioxidant enzymes acted against the ROS effects: in other words they executed ROS scavenging activity by the help of an antioxidant agent CVD. The chosen intraperitoneally administered dosage of CVD followed the previous studies related with I/R injury and CVD administration to avoid OS $(1,10,12)$.

In this study, the histopathological changes associated with TT injury in the acute phase were mild. The statistical analysis of the investigated parameters, especially mean Johnsen scores, yielded non-significant differences between all of the groups. This may be attributed to the prementioned issue that morphologic changes occur later in $I / R$ injury in comparison to biochemical alterations. Consequently, not to investigate the lately seen pathological changes in the rat testis due to TT in another group may be the limitation of this study. Additional studies are required to examine late histopathologic effects of I/R injury in the rat testis and chronic usage of CVD treatment.

\section{CONCLUSIONS}

The data obtained by the biochemical and pathological examinations of the testicular tissues of rats supported that TT caused I/R injury in the rat testis as evidenced by the alterations in oxidative parameters both in serum and testicular tissues. The results also demonstrated that treatment with CVD attenuated the $\mathrm{I} / \mathrm{R}$ induced testicular damage through activation of antioxidant mechanisms. These results may provide a potential therapeutic value in the treatment of post-ischemic testicular damage and improve the fertility potential of the patients who had testicular torsion and detorsion event in the clinical base.

\section{ACKNOWLEDGEMENTS}

The authors are grateful to the support given by Unal Erkorkmaz Ph.D. (Sakarya University School of Medicine, Department of Biostatistics and Bioinformatics, Sakarya-Turkey) in the statistical analysis of the results.

\section{CONFLICT OF INTEREST}

None declared. 


\section{REFERENCES}

1. Akbas H, Ozden M, Kanko M, Maral H, Bulbul S, Yavuz S, et al.: Protective antioxidant effects of carvedilol in a rat model of ischaemia-reperfusion injury. J Int Med Res. 2005; 33: 528-36.

2. Cay $A$, Alver $A$, Küçük M, Işik 0, Eminağaoğlu MS, Karahan SC, et al.: The effects of $\mathrm{N}$-acetylcysteine on antioxidant enzyme activities in experimental testicular torsion. J Surg Res. 2006; 131: 199-203.

3. Unsal A, Devrim E, Guven C, Eroglu M, Durak I, Bozoklu A,et al.: Propofol attenuates reperfusion injury after testicular torsion and detorsion. World J Urol. 2004; 22: 461-5.

4. Altunoluk B, Söylemez H, Bakan V, Ciralik H, Tolun Fl: Protective effects of zofenopril on testicular torsion and detorsion injury in rats. Urol J. 2011; 8: 313-9.

5. Uz E, Söğüt S, Sahin S, Var A, Ozyurt H, Güleç M, Akyol O: The protective role of caffeic acid phenethyl ester (CAPE) on testicular tissue after testicular torsion and detorsion. World $\mathrm{J}$ Urol. 2002; 20: 264-70.

6. Can C, Töre F, Tunçel N, Uysal O, Gürer F, Ak D, Tunçel $\mathrm{M}$ : Protective effect of vasoactive intestinal peptide on testicular torsion-detorsion injury: association with heparincontainingmast cells. Urology. 2004; 63: 195-200.

7. Koc A, Narci A, Duru M, Gergerlioglu HS, Akaydin Y, Sogut $\mathrm{S}$ : The protective role of erdosteine on testicular tissue after testicular torsion and detorsion. Mol Cell Biochem. 2005; 280: 193-9.

8. Dokmeci D, Inan M, Basaran UN, Yalcin 0, Aydogdu N, Turan FN, Uz YH: Protective effect of L-carnitine on testicular ischaemiareperfusion injury in rats. Cell Biochem Funct. 2007; 25: 611-8.

9. Yurtçu M, Abasiyanik A, Avunduk MC, Muhtaroğlu S: Effects of melatonin on spermatogenesis and testicular ischemiareperfusion injury after unilateral testicular torsion-detorsion. J Pediatr Surg. 2008; 43: 1873-8.

10. Singh D, Chander V, Chopra K: Carvedilol attenuates ischemiareperfusion-induced oxidative renal injury in rats. Fundam Clin Pharmacol. 2004; 18: 627-34.

11. Hayashi T, De Velasco MA, Saitou Y, Nose K, Nishioka T, Ishii T, et al.: Carvedilol protects tubular epithelial cells from ischemiareperfusion injury by inhibiting oxidative stress. Int $\mathrm{J}$ Urol. 2010; 17: 989-95.

12. Hayashi T, Saitou $Y$, Nose $K$, Nishioka T, Ishii T, Uemura $H$ : Efficacy of carvedilol for ischemia/reperfusion-induced oxidative renal injury in rats. Transplant Proc. 2008; 40: 2139-41.

13. Yue TL, Ma XL, Gu JL, Ruffolo RR Jr, Feuerstein GZ: Carvedilol inhibits activation of stress-activated protein kinase and reduces reperfusion injury in perfused rabbit heart. Eur $\mathrm{J}$ Pharmacol. 1998; 345: 61-5.

14. Yasar A, Erdemir F, Parlaktas BS, Atilgan D, Koseoglu RD, Saylan 0 , et al.: The effect of carvedilol on serum and tissue oxidative stress parameters in partial ureteral obstruction induced rat model. Kaohsiung J Med Sci. 2013; 29: 19-25.
15. Dieckmann KP, Linke J, Pichlmeier U, Kulejewski M, Loy V; German Testicular Cancer Study Group: Spermatogenesis in the contralateral testis of patients with testicular germ cell cancer: histological evaluation of testicularbiopsies and a comparison with healthy males. BJU Int. 2007; 99: 1079-85.

16. Elshaari FA, Elfagih RI, Sheriff DS, Barassi IF: Oxidative and antioxidative defense system in testicular torsion/detorsion. Indian J Urol. 2011; 27: 479-84.

17. Tamamura M, Saito M, Kinoshita Y, Shimizu S, Satoh I, Shomori $\mathrm{K}$, et al.: Protective effect of edaravone, a free-radical scavenger, on ischaemia-reperfusion injury in the rat testis. BJU Int. 2010; 105: 870-6.

18. Wei SM, Yan ZZ, Zhou J: Beneficial effect of taurine on testicular ischemia-reperfusion injury in rats. Urology. 2007; 70: 1237-42.

19. Ozturk H, Ozturk H, Gideroglu K, Terzi H, Bugdayci G: Montelukast protects against testes ischemia/reperfusion injury in rats. Can Urol Assoc J. 2010; 4: 174-9.

20. Filho DW, Torres MA, Bordin AL, Crezcynski-Pasa TB, Boveris $A$ : Spermatic cord torsion, reactive oxygen and nitrogen species and ischemia-reperfusion injury. Mol Aspects Med. 2004; 25: 199-210.

21. Jeong SJ, Choi WS, Chung JS, Baek M, Hong SK, Choi H: Preventive effects of cyclosporine a combined with prednisolone and melatonin on contralateral testicular damage afteripsilateral torsion-detorsion in pubertal and adult rats. J Urol. 2010; 184: 790-6.

22. Yíldíz H, Durmus AS, Simşek H, Yaman M: Protective effect of sildenafil citrate on contralateral testis injury after unilateral testicular torsion/detorsion. Clinics (Sao Paulo). 2011; 66: 137-42.

23. Azizollahi S, Babaei H, Derakhshanfar A, Oloumi MM: Effects of co-administration of dopamine and vitamin $C$ on ischaemiareperfusion injury after experimental testiculartorsion-detorsion in rats. Andrologia. 2011; 43: 100-5.

24. Unal D, Karatas OF, Savas M, Yeni E, Keser BS, Verit A, et al.: Protective effects of trimetazidine on testicular ischemiareperfusion injury in rats. Urol Int. 2007; 78: 356-62.

25. Kanter M: Protective effects of Ginkgo biloba (EGb 761) on testicular torsion/detorsion-induced ischemia-reperfusion injury in rats. Exp Mol Pathol. 2011; 91: 708-13.

26. Lysko PG, Webb CL, Gu JL, Ohlstein EH, Ruffolo RR Jr, Yue TL: A comparison of carvedilol and metoprolol antioxidant activities in vitro. J Cardiovasc Pharmacol. 2000; 36: 277-81.

Correspondence address: Bekir Suha Parlaktas, MD Gaziosmanpasa Üniversitesi Tıp Fakültesi, Üroloji AD 60100, Tokat, Turkey Fax: +90 356 212-9417 E-mail: bsuha@mynet.com 